\title{
INTERPRETING ELEMENTS AND ISOTOPES IN GLASS:
}

\section{A REVIEW*}

\author{
P. DEGRYSE \\ Department of Earth and Environmental Sciences, Katholieke Universiteit Leuven, Celestijnenlaan 200 E \\ B-3001 Heverlee, Belgium and Faculty of Archaeology, Leiden University, Einsteinweg 2 NL-2333 CC \\ Leiden, The Netherlands \\ and A. J. SHORTLAND† \\ Cranfield Forensic Institute, Cranfield University, Defence Academy of the UK, Shrivenham SN6 8LA, UK
}

\begin{abstract}
Substantial databases of elemental and isotopic analyses of ancient glass exist and are used to investigate raw material origin, trade, exchange, and processes such as mixing and recycling. However, the chemistry of archaeological glass may be challenging to the untrained. The paper provides structured information on the origin of chemical elements and their isotopes in ancient glass. It details some of the functions of individual elements in the glass and from which raw material(s) or process(es) they originate.
\end{abstract}

KEYWORDS: GLASS, COLORANT, DECOLORANT, FLUX, NETWORK FORMER, PERIODIC TABLE

\section{INTRODUCTION}

Glass objects, mostly in the form of beads, are occasionally found in the archaeological record from the late third millennium BCE onwards. Nevertheless, it took until the Late Bronze Age (LBA) (16th-15th centuries BCE) before regular and controlled glass production was active in the major ancient centres of the Near East, Egypt and Mediterranean. Glass at that time was strongly coloured and intended as a high-status material, equivalent to semiprecious stones. At the end of the LBA, and the second millennium BCE, considerable social change spread across the Mediterranean with the collapse and disappearance of the great states of the time. This is believed to have affected dramatically the glass industry with a breakdown of trade and exchange networks. Glass becomes relatively rare, but reappears by the 10th-9th centuries BCE, again initially rarely, and generally in the form of strongly coloured beads or vessels. Significantly, this new glass also has new raw materials leading to a new composition. The invention of glassblowing somewhere in the first century BCE and its rapid spread throughout the Roman Empire makes glass a daily, utilitarian, commodity by the first century CE. By then, strong coloured glass has been largely replaced by weakly coloured (blue and green) and colourless glass, used as an everyday household material. Glass in Byzantine, Islamic, medieval and up to modern times essentially remains the same: a translucent, lightly coloured or colourless everyday material.

It is generally accepted that raw glass was widely traded, for example, as ingots of coloured glass in the LBA or as chunks of colourless or naturally coloured glass in the Roman and early medieval periods. In this way, glass-making sites are separated from glass-shaping or -forming

\footnotetext{
*Received 8 October 2019; accepted 25 November 2019

†Corresponding author: a.shortland@cranfield.ac.uk

(C) 2019 University of Oxford
} 
sites. Much like with ceramic studies, questions asked in glass research relate to the type of raw materials used, the technology and provenance of the produce, and reconstructing trade, exchange and recycling. These studies are tackled through the chemical analysis of glass objects or raw materials that run alongside longstanding work on typology of vessels shapes, for example.

In terms of raw materials, the great majority of ancient glass was chemically based upon silica or (much later and rarer) $\mathrm{Pb}$, fluxed with soda or potash to lower the melting temperature. The earliest known soda (-lime-silica) glass was found in LBA Mesopotamia and Egypt, and continued as the dominant compositional type of glass across Western Asia and the Mediterranean right up to the modern period. K-rich glasses are confined largely to medieval Europe and to Asia. The manufacture of colourless $\mathrm{Pb}$-based glass has been largely restricted to tablewares, and mostly from the 17th century $\mathrm{CE}$ onwards, though Han dynasty Chinese, Roman and Islamic high- $\mathrm{Pb}$ (opaque) glass exists. This paper does not aim to cover the whole area of glass production; it would be impossible to do so in the length allowed. It covers as many compositions as it can, and draws examples mostly from the Mediterranean world.

Specific compositions of glass indicate certain sources, technical processes and periods. Concentrations of major elements allow glass types and raw materials to be identified. Substantial databases of major, trace element and isotopic analyses of glass exist (e.g., Brill 1999; Brill and Stapleton Brill 2012; Degryse 2014), and are used to investigate trade, exchange and technical processes such as mixing and recycling. As the elemental chemistry of archaeological glass may be challenging for untrained, this paper assists in this by discussing the function of individual elements in the glass and where they originate. Basic information on the nature and origin of chemical elements and their isotopes in glass is provided, and references to further examples and applications in literature are given.

\section{Glass flux types: $\mathrm{Na}, \mathrm{K}$ (with $\mathrm{Rb}, \mathrm{Cs}$ ), $\mathrm{Mg}, \mathrm{P}, \mathrm{B}, \mathrm{Sr}, \mathrm{Cl}, \mathrm{S}$}

To lower the melting temperature of the network former, silica, in a glass to temperatures easily achieved in ancient technological processes, a flux or melting-aid has to be added. Mixed with the silica, soda or potash work well as a flux, forming a so-called eutectic melt. In ancient soda-lime-silica glass, two major types of flux are used, defining two major categories of glass (Sayre and Smith 1961): (1) plant ash glass, combining a plant ash with quartz pebbles; and (2) natron glass, combining soda-rich evaporitic minerals with quartz sand.

The ashes of beach and desert plants were used as flux in the earliest glass from the LBA onwards for more than a millennium to produce what is widely called plant ash glass. The most essential characteristic of the plants used is the presence of high contents of sodium carbonate or bicarbonates, and possibly hydroxides. Especially suitable for glass-making are the salt-resistant plants growing in semi-arid or saline maritime environments. Examples mentioned in literature are the genera Salicornia and Salsola of the Chenopodiaceae family (Tite et al. 2006; Henderson 2013, 2013). Other types of plants may also have been used for LBA and Iron Age glass-making, possibly providing ashes higher in potash, used as the flux source in so-called mixed alkali glass (Tite et al. 2006). Most LBA glasses reach soda levels between 14 and $20 \mathrm{wt} \%$. Accompanying elements in the plant ash include a significant input of silica and lime $(\mathrm{CaO})$, with elevated $\mathrm{Mg}, \mathrm{K}$ and $\mathrm{P}$ contents and significant other accessory and trace elements (for instance, $\mathrm{Rb}$ and even $\mathrm{Cs}$, which have a high affinity with K) (Freestone 2006). LBA glass made with halophytic plants are called 'high magnesium-high potassium' (HMHK) glass, while their mixed alkali equivalents are termed 'low magnesium-high potassium' (LMHK) glass. However, the relationship between 
the chemical composition of certain plants, their ashes and the glasses produced from them is complex. This is caused by various factors, the most important ones being the geochemical composition of the soil on which the plants grow, the use (parts) of specific plant species and genera, and the ashing and melting conditions before and during glass production (Henderson 2013a, 2013b).

Mineral soda (natrun or natron, mainly lake deposited sodium carbonates such as natron and trona. However, often mixed with sulphates and other salts such as burkeite or halite) they gradually took over the function of flux in the early first millennium BCE. Natron glass was the predominant type of ancient glass in the Mediterranean, Europe and Near East west of the Euphrates River, from the mid-first millennium BCE to the ninth century CE (Freestone et al. 2002a; Shortland 2004). To the east, plant ash continued to be used as a flux, probably reflecting the lack or poor availability of natron or raw natron glass there (Shortland et al. 2006). Natron or sodium carbonates in their pure form do not occur in nature frequently. An overview of the known sources of natron in antiquity is given by Shortland et al. (2006), pointing to Egypt, and most likely Wadi Natrun and al-Barnuj, as the main supplier of natron in the ancient world, hereby corroborating the words of Pliny the Elder (Nat. Hist. XXXI, 111). To date, however, there is no direct evidence that soda from Wadi Natrun was exported for glass production outside Egypt. Moreover, one also needs to be aware of the enormous amounts of natron used in glass production, and it is uncertain whether the Egyptian lakes could on their own supply these vast quantities. Devulder et al. (2015) have demonstrated the presence of natron deposits in the whole of Northern Africa, and have suggested the possibility of their use alongside the Egyptian sources. Elementally, natron deposits are very pure, and beside soda contribute very little to the final glass composition. Boron (B) is brought into natron glass mostly from the flux, and the B isotopic composition of evaporites has been used to try to distinguish different sources of this raw material (Devulder et al. 2014, 2015). B shows a wide spread in its isotopic composition in nature and has proven useful in the geochemical provenancing of evaporates in geology. Rarely, ancient high B glass ( $>1000$ ppm B) has been recorded, where B plays an important role in compositional grouping and provenancing such glass (cf. glass network former).

Around the ninth century CE, perhaps due to difficulties in the supply of natron throughout the Mediterranean and Europe, plant ashes once again became dominant flux (Freestone 2006), using varied sources of ash. While Venetian glassmakers monopolized the import of Syrian plant ashes similar to the earlier Bronze Age glass raw material, in Northern medieval Europe glassmakers experiment with the use of ashes of wood (in particular, beech; e.g., Wedepohl and Simon 2010) or the use of mixed alkali (e.g., Wedepohl et al. 2011) or even fern, bracken or kelp as a flux (Dungworth et al. 2009; Dungworth, 2012).

As for major and minor constituents of glass, the elements $\mathrm{Mg}, \mathrm{K}$ and $\mathrm{P}$ separate plant ashbased glasses (now interpreted as all plant ashes, from halophytic plants to wood, fern, bracken, kelp, etc.) from natron-based glasses, also called 'low magnesium-low potassium' (LMLK) glass. Usually, contents $>1.5 \%$ in both $\mathrm{MgO}$ and $\mathrm{K}_{2} \mathrm{O}$ are thought to indicate the use of plants as a flux, while $\mathrm{P}_{2} \mathrm{O}_{5}$ contents may reach close to $1 \%$ in plant ash glasses. Along with HMHK and LMHK glasses, an additional subdivision may usefully be recognized for post-ninth-century plant ash glass (Freestone 2006). Plant ash glasses from the Syria-Palestine region have compositions with $\mathrm{K}_{2} \mathrm{O}$ and $\mathrm{MgO}$ of 2.0-3.5\% (e.g., from the Serçe Limani wreck, Brill 1999; Banias, Freestone et al. 2000; and Tyre, Freestone 2002), while plant ash glasses made up to the seventh century CE to the east of the Euphrates, in the region of the Persian Empire under the Parthians and Sasanians, tend to have $\mathrm{MgO}$ and $\mathrm{K}_{2} \mathrm{O}$ contents $>3.5 \%$. However, a difficulty in resolving 
plant ash glass provenance is that our understanding of the manufacture of this type of glass is very limited.

The earliest wood ash fluxed glass, also known as forest glass, produced in medieval Europe in a few initially heavily forested areas, is likely made with beech and other woods or bracken with high but variable contents in potash, soda, magnesia and lime (Dungworth 2012). A further glass type with a very high lime content, as in so-called high lime-low alkali (HLLA) glass, has also been tentatively assigned to the use of wood ash (Dungworth 2011). Kelp glass can be recognized by its very high (>1000 ppm) Sr contents (Dungworth 2012). For (post)-medieval plant ash glasses, Wedepohl and co-workers (Wedepohl and Simon 2010; Wedepohl et al. 2011, 2011b) suggested a series of trace elements specific to the wood ash used in glass production ( $\mathrm{Sr}, \mathrm{Rb}, \mathrm{Zn}, \mathrm{Ni}, \mathrm{Cu}, \mathrm{B}, \mathrm{Ba}, \mathrm{Mn}$ ) might offer the potential to characterize such glass from certain regions.

Almost all fluxes contain quantities of chlorides or sulphates. These are unwanted, because of their practically non-reactivity in the glass batch (Tite et al. 2006), and can form immiscible glasses on top of the silicate glasses beneath. They enter the glass composition in limited amounts $(0.5-1.0 \%)$, but rarely more. By the mid-19th century $\mathrm{CE}$, the production of synthetic soda through the Leblanc process becomes common and goes on to provide the bulk of the flux used in the modern glass industry (Dungworth 2012). The use of this synthetic soda produces a sodasilica-lime glass with low $\mathrm{K}$ content and little to no $\mathrm{P}$ or $\mathrm{Cl}$, a useful marker for modern glass compared with historical or ancient.

\section{Glass stabilizer: $\mathrm{Ca}, \mathrm{Mg}, \mathrm{Sr}$}

The eutectic mixture of network former and flux in a glass needs to be stabilized by lime and/or magnesia. Without stabilizing elements, the resulting glass is soluble in water, a property not usually desirable in man-made vitreous materials. In plant ash glasses, it is usually thought that no additional lime needs to be added as it is sufficiently present in the plant ash itself (Barkoudah and Henderson 2006). However, cuneiform glass-making texts do suggest that lime might be added in addition (Shortland 2012). In later natron-based glasses, however, the mineral soda introduces virtually no lime into the glass batch. Consequently, lime in natron glass is mainly derived from particles of shell or limestone, either added on purpose or naturally occurring in the silica source (Freestone 2006). Another, unintentional, incorporation of lime might happen by the partial dissolution of the crucible linings used into the glass batch, or through contamination by fuel ash (Shortland 2012).

The concentration of $\mathrm{Sr}$ in natron glass artefacts is a useful indicator of the form in which the lime source was added during production. Owing to their similar atomic radius, Sr substitutes for $\mathrm{Ca}$ in Ca-rich minerals, in particular calcite and aragonite. Aragonitic shells and marine biogenic carbonates contain relatively high concentrations of Sr (Wedepohl and Baumann 2000): values fluctuate between 8000 and $1200 \mathrm{ppm} \mathrm{Sr}$ for, respectively, aragonite and calcite in equilibrium with seawater. In contrast, diagenetic alteration means that Mesozoic and Palaeozoic limestones only contain a few hundred ppm Sr. As a consequence, a low Sr content of $<200 \mathrm{ppm}$ in the final glass points to the use of geological limestone, while higher Sr concentrations between 300 and $600 \mathrm{ppm}$ suggest the use of (Holocene) beach shell fragments. Some other elements, such as $\mathrm{Mg}$, $\mathrm{Fe}, \mathrm{P}$ and $\mathrm{Mn}$, could potentially be incorporated into glass via the lime source, but only at very minor levels $(<0.1 \mathrm{wt} \%)$. Also, most trace elements and rare earth elements (REE) only occur in negligible amounts in lime sources compared with the concentrations commonly found in sand used as a silica source (Wedepohl et al. 2011b; Brems and Degryse 2013), so once again the lime 
source will not bring significant amounts of these elements into the glass. In relatively modern glasses, the evolution of manufacturing techniques between the two World Wars, saw replacement of a proportion of the calcite-based lime in glass by dolomite-based lime and $\mathrm{Mg}$. This is helped to overcome devitrification problems (Dungworth 2012).

The application of $\mathrm{Sr}$ isotope analysis in research on ancient glass depends primarily on the assumption that the $\mathrm{Sr}$ in the glass is incorporated with the lime-bearing constituents (Wedepohl and Baumann 2000). It has been assumed that the contribution of natron to the Sr balance of glass is negligible (Freestone et al. 2003), and minor contributions may be attributed to non-quartz minerals in the silica raw material (Freestone et al. 2003; Degryse et al. 2006). Where the lime in a natron glass was derived from recent beach shell, the $\mathrm{Sr}$ isotopic composition of the glass is close to that of modern seawater (Wedepohl and Baumann 2000; Freestone et al. 2003). Where the lime was derived from geological limestone deposits, the Sr signature in the glass is a reflection of seawater at the time this limestone was deposited, possibly modified by diagenetic alteration (Freestone et al. 2003). Plant ash glasses are likely to have been produced from low-lime sand or (pure) quartz pebbles (e.g., Henderson et al. 2005). In this case, Sr in the glass is derived from the plant ash, the isotope ratio thus reflecting the bioavailable $\mathrm{Sr}$ of the soil in which the plants grew. This, in part, reflects the geological origin of the soil (Freestone et al. 2003). Both the $\mathrm{Sr}$ isotopic ratio and $\mathrm{Sr}$ concentrations are thus useful indicators. Sr concentrations in plant ash glass often show a considerable variability, indicative of the varied or complex source of the $\mathrm{Sr}$ and the concentrating effect of ashing the plant (Henderson et al. 2005; Barkoudah and Henderson 2006). Henderson et al. (2009) illustrate how important it is to establish variations in $\mathrm{Sr}$ isotope signatures in the landscape as part of trying to provide a provenance for plant ash glasses. A first survey of the $\mathrm{Sr}$ isotopic composition of glass throughout the ancient world has indicated its use in classifying glasses of the world according to their origin (Brill and Fullagar 2006). The effects of recycling on the Sr isotopic composition of glass have been studied by Degryse et al. (2006; 2010). In this study, mixing lines and a plot of isotope signatures versus concentrations demonstrated that the $\mathrm{Sr}$ in a local, glassworking site was a mixture of the signatures of two imported end members.

\section{Glass network former: $\mathrm{Si}, \mathrm{O}, \mathrm{Al}, \mathrm{Fe}, \mathrm{Ti}, \mathrm{Cr}, \mathrm{Zr}, \mathrm{REE}$ with $\mathrm{Nd}, \mathrm{Pb}$ (with $\mathrm{Ba}$ ) et al.}

Tracing the silica source is a good starting point for provenancing ancient glass, since it makes up the bulk of the glass, about $60-75 \mathrm{wt} \%$ in all but high-Pb glasses. Potential sources include coastal and inland sands, quartz pebbles and other geological deposits such as vein quartz, chert or quartzite. Quartz pebbles are a relatively pure source of silica (Shortland 2012). Only a few elements may be incorporated into the crystal structure of quartz and then only in trace quantities. Nevertheless, quartz pebble deposits regularly contain upwards from $0.5 \mathrm{wt} \%$ of alumina $\left(\mathrm{Al}_{2} \mathrm{O}_{3}\right)$, iron oxide $\left(\mathrm{Fe}_{2} \mathrm{O}_{3}\right)$ or titanium oxide $\left(\mathrm{TiO}_{2}\right)$, usually in the form of associated $\mathrm{Fe}$ (hydr)oxides or clay minerals. In contrast, a silica sand source can contain a wide range of minor and trace elements associated with the different accessory minerals mixed with the quartz sand through common geological and geographical processes (Wedepohl et al. 2011, 2011b). Elements such as $\mathrm{Fe}$, Ti and alumina are usually related to the concentrations of specific minerals (feldspars, clays, etc.) in the sand. Concentrations of lime and alumina are sometimes used to subdivide natron glasses into groups, as these elements reflect the silica and lime source (be it as separate constituents or as one sand raw material; Freestone et al. 2000).

Some elements are strongly concentrated in specific minerals, while other elements are taken up in minor amounts into non-quartz or heavy minerals. Examples of elements that concentrated 
into their own minerals are $\mathrm{Zr}$ in zircon, $\mathrm{Ti}$ in rutile, ilmenite or titanite, $\mathrm{Ba}$ in barite and $\mathrm{Cr}$ in chromite. Their distribution is mainly controlled by heavy mineral concentration processes (Degryse and Shortland 2009). Through the same processes, other detrital minerals from weathered ore deposits, such as galena $(\mathrm{Pb})$ or sphalerite $(\mathrm{Zn})$ might contribute their particular metal in the final glass composition (Wedepohl et al. 2011). Elements such as $\mathrm{Ca}, \mathrm{Fe}, \mathrm{Mg}$ and $\mathrm{Al}$ enter the glass batch with minerals such as feldspars, clay, pyroxene, amphibole, mica and calcite, commonly occurring in sand. Feldspars have K-, Na- and Ca-rich compositions. Ba, $\mathrm{Rb}, \mathrm{Cs}$ and $\mathrm{Sr}$ can be related to these and other silicate minerals, substituting for the alkali or $\mathrm{Ca}$ (Brems and Degryse 2013). The presence of elements such as Sc, V, Cr, Co and Ni is usually related to the occurrence of Fe oxides or olivine. Hf and Y are mostly found in the heavy mineral zircon, while $\mathrm{Nb}$ occurs in rutile. Th and La are dispersed throughout the mineral monazite, and $\mathrm{B}$ is an important constituent of tourmaline. Also the elements $\mathrm{Li}, \mathrm{P}, \mathrm{Mo}, \mathrm{Cs}, \mathrm{Bi}$, Th and $\mathrm{U}$ in glass are probably related to the sand raw material (Brems and Degryse 2013, passim). The observation that 25 minor elements (Be, Sc, V, Cr, Ge, Y, Nb, REE ( $\mathrm{La}$ to $\mathrm{Lu}$ ), Ta, W and $\mathrm{Bi}$ ) occurred in almost equal concentrations in all subtypes of wood ash glass, was interpreted as the fact that these elements originated from the silica source of the glass (Wedepohl and Simon 2010).

Trace elements in glass can help to separate compositional groups and assign individual objects to them, although the application of trace elements in glass provenancing so far has remained limited. De Raedt et al. (1999) have studied the provenance of Venetian and Façon de Venise glasses of the 16th-17th centuries, while Freestone et al. (2000, 2002b) and Aerts et al. (2003) have investigated trace elements as more specific indicators of origin of Roman to Byzantine/Islamic glass raw materials. Trace element analysis has been most successful in provenancing LBA plant ash glasses (Shortland 2005; Shortland and Eremin 2006; Shortland et al. 2007; Walton et al. 2009). Analysis showed trace element variations in especially $\mathrm{Ti}, \mathrm{Zr}$, $\mathrm{Cr}$ and La contents, which allowed glass from Egyptian sites to be distinguished from that found on Mesopotamian sites. These differences may reflect varying plant ash compositions between the two areas, differences in silica source compositions and/or contamination of the melt by clay or grinding debris (Shortland 2005; Rehren and Pusch 2005; Shortland et al. 2007).

REE (La, Ce, Pr, Nd, Sm, Eu, Gd, Tb, Dy, Ho, Er, Tm, Yb and Lu) are used to distinguish sand raw materials from various geological environments. In such studies, REE compositions are normalized to the Earth's continental crust composition, and described as enriched or depleted compared with the average crust. This in contrast to other studies, where REE concentrations are normalized to values in chondritic meteorites. However, in quartz-rich sands, the REE are mainly concentrated in the clay and silt fraction, and earlier studies have indicated that only fundamental changes in regional geology would result in different REE profiles (Degryse and Shortland 2009; Walton et al. 2009). Within the REE, Nd is inherited in glass from the nonquartz mineral content of the silica raw material used. Since as no high Nd glasses are known in the archaeological record, the effect of glass recycling on the $\mathrm{Nd}$ composition of a glass batch is thought to be not significant and will not change significantly with the addition of colorants or opacifiers. This means that $\mathrm{Nd}$ isotopes offer great potential in tracing the origins of the silica in primary glass production and, therefore, the glass itself. Since the initial paper by Degryse and Schneider (2008), several groups have applied $\mathrm{Nd}$ isotopes to trace the silica sources of early Bronze Age to Roman and Byzantine glass production around the Mediterranean. For a full review of the use of $\mathrm{Nd}$ isotopes in reconstructing the Greco-Roman glass economy, see Degryse (2014).

$\mathrm{O}$ isotopes were one of the first systems to be applied to provenancing ancient vitreous materials (Brill 1970). There is a natural range in isotopic values of quartz sands and quartz veins or 
pebbles depending on their geological origin, for example, erosion from magmatic rocks, hydrothermal formation and metamorphic conditions. It is stated by Brill (1970) and Brill et al. (1999) that the $\mathrm{O}$ isotopic composition of ancient glass will be mainly dependent on the silica source, as it is the predominant component, with minor influences of flux and stabilizer. However, the use of $\mathrm{O}$ isotopes in recent studies has been limited, possibly because of the large overlaps in isotopic signature between many possible silica sources for ancient glass-making (Leslie et al. 2006; Silvestri et al. 2010).

As mentioned above, exceptional glass compositions with very high B and alumina contents have been recognized. In general, a high alumina composition is commonly associated with India and Southeast Asia more widely (Brill, 1987). The study of Dussubieux et al. (2010) of Indian glass found in Africa, South Asia and Southeast Asia revealed a wide variety of aluminarich glass compositions. Glass with alumina concentrations $>4 \mathrm{wt} \%$ in combination with $\mathrm{B}$ $>500 \mathrm{ppm}$ is rare in ancient times (Schibille 2011; Purowski et al. 2012; Rehren et al. 2015; Conte et al. 2016), but occur over two millennia in Turkey and parts of Europe. They are thought to be associated with a possible production location in Turkey, although it is not known whether the considerable B amounts are derived from the sand or the flux, and the exact location of their origin has not yet been proven.

$\mathrm{Pb}$ glass occurs in Han China (second century BCE-third century $\mathrm{CE}$ ), and differs significantly from the contemporaneous Western silica-natron glass tradition. Pb takes up the function as network former, flux and stabilizer in this glass type, instead of silica, soda or potash and lime. This glass typically also contains several weight per cent $\mathrm{Ba}$. The late date for making glass in China may suggest that the technology was brought from the Middle East along the Silk Road (Fuxi et al. 2009), but the fundamental difference in technology could indicate an autonomous development. High $\mathrm{Pb}$ glasses in the West are rare, but some high $\mathrm{Pb}$ Roman glass does exist. In medieval and later Europe, $\mathrm{Pb}$ glass was used as a base glass for mosaics, enamels, stained glass and also in glazes, while $\mathrm{Pb}$ was added to Islamic plant ash glass in Spain to produce a particular composition (Duckworth et al. 2015). Colourless Pb-based (crystal) tableware only occurs from the 17th century CE onwards (Dungworth 2011).

\section{Classic glass colorants and associated elements: $\mathrm{Co}, \mathrm{Cu}, \mathrm{Sb}, \mathrm{Pb}, \mathrm{Mn}, \mathrm{Sn}, \mathrm{As}, \mathrm{Zn}, \mathrm{Ni}, \mathrm{Ba}$}

The most striking feature of ancient glass is often its colour, obtained naturally or intentionally via the use of (de)colourizers and a careful control of furnace parameters, and resulting in a wide variety of hues (Jackson 2005). Some minor elements in ancient glass are typically associated with the intentional colouring or decolouring of the material, such as Sb for opacifying or decolouring, Mn for decolouring or a purple colour, Co for a deep blue colour, $\mathrm{Cu}$ for blues, blue/green or a red colour, $\mathrm{Sn}$ for an opaque white appearance, etc. (Henderson 2000), and $\mathrm{Pb}$ with $\mathrm{Sb}$ or Sn for opacified yellow glasses. Such elements are often added as separate constituents in the form of ores (e.g., stibnite), minerals (e.g., alum), metals (e.g., bronze) or an intermediate compound derived from them, and they have a wide range of associated (trace) elements. In certain circumstances, the use of minerals to (de)colour a glass will have a significant effect on the compositions of those elements present in the material, and hence these elements can no longer be used to provenance the silica or flux raw material, or should at the very least be treated with the necessary caution. Moreover, while the element $\mathrm{Cl}$ in ancient glass is usually considered to enter the glass batch with the flux material, S can originate from the flux or sulphate/sulphide ores used as (de)colorants. 
Co is one of the strongest colouring elements, with $0.10 \% \mathrm{CoO}$ enough to colour a glass a distinctive blue. Co is also one of the most useful in that it commonly occurs in its ore with a range of other elements such as $\mathrm{Fe}, \mathrm{As}, \mathrm{Mn}, \mathrm{Ni}, \mathrm{Zn}, \mathrm{Bi}$ and others. These associated elements are often carried into the glass with the Co pigment, and often act as a trace element fingerprint which can indicate the Co ore source. In some cases, the Co pigments, often transported as a glass colorant called 'smalt' can travel large distances. European smalt Co pigments have been identified in the enamelled porcelains of 18th-century China, for example (Giannini et al., 2017; see Gratuze 2013 for a good summary).

$\mathrm{Sb}$ was widely used as an opacifier in glass from the LBA onwards. Ca antimonate (white) and $\mathrm{Pb}$ antimonate (yellow) are commonly found, while $\mathrm{Sb}$ was also added to blue glasses to achieve opaque turquoise (Shortland 2012). Interestingly, Sb gains a second use as a decolorant in the Greco-Roman period, until replaced by Sn-based opacifiers or Mn-based decolorants around the fourth century CE (Tite et al., 2008). The most likely raw materials used are Mn- and Sb-bearing minerals, such as pyrolusite $\left(\mathrm{MnO}_{2}\right)$ and stibnite $\left(\mathrm{Sb}_{2} \mathrm{~S}_{3}\right)$. Sn can be added as cassiterite $\left(\mathrm{SnO}_{2}\right)$ or could come from bronze scrap or more generally $\mathrm{Cu}$ alloys (associated with As or $\mathrm{Sb}$ ). $\mathrm{Sb}$ ores may also bring As to a glass batch, while Ba may be introduced through the Mnbearing mineral used as a decolourizer (or as an impurity in the sand), associated with mineral such as, for example, psilomelane. Mn decolouring of glass has been known to influence the $\mathrm{Sr}$ isotopic composition of the glass (Ganio et al. 2012). Despite the fact that many analytical studies have been devoted to decolourizing agents, compositional analysis has not been able to reveal the provenance of the ores used, although the Caucasus has been suggested (Shortland 2002). A new way to investigate the provenance of Sb in glass is by isotopic analysis, for which the analytical methods have recently been developed (Lobo et al. 2014). This approach may help determine the origin of Sb in early glass artefacts, where it is used as an opacifier, possibly following the development of Sb metallurgy in the Caucasus during the Bronze Age (Degryse et al. 2015).

The largest share of ancient translucent glass from Greco-Roman times onwards has a bluegreen colour owing to Fe impurities introduced into the glass via the raw materials (Jackson 2005), usually in the form of silicates other than quartz or as Fe oxides. The Fe content of the glass may then be associated with such elements as $\mathrm{Ti}, \mathrm{Zr}$ or $\mathrm{Cr}$. An increasing popularity of colourless glass can be observed from the early Roman period (first century CE) onwards. Colourless glass can be produced either by selecting raw materials that are low in Fe minerals (high-purity sands) or, more commonly, by the addition of a decolourizing agent. Sb is a more efficient decolourizer than $\mathrm{Mn}$ and results in a more brilliant glass, likely by removing dissolved gases (Jackson 2005).

An important factor to take into account in the analyses of trace elements in ancient glass is the fact that the presence of elevated contents in metals such as $\mathrm{Pb}, \mathrm{Zn}$ or $\mathrm{Cu}$ may indicate that scrap glass, including small quantities of coloured glass or metal-coated glass, was incorporated in a glass batch, pointing to 'recycled' material. The (trace) elemental composition of an ancient glass can be easily altered by mixing raw materials, recycling of scrap glass or the addition of mineral matter as a separate constituent to the glass batch, complicating any interpretation of glass analyses.

Weird and wonderful glass colorants: $\mathrm{Au}, \mathrm{Cr}, \mathrm{Cd}, \mathrm{Se}, \mathrm{U}$

Whilst many of the colorants discussed above have been widely used across the world to create coloured glasses and, indeed, glazes, and may well have been independently discovered in more 
than one place, other technologies, particularly the later more modern ones, are very likely to have been discovered only once. They are severely limited in time frame and usually geographical spread and, therefore, are very useful for dating and provenancing glass. Au was used in high-status glass from the third century CE in Rome (Walker et al. 2018). Here it is sandwiched in the glass as Au leaf between two glassy layers. However, more importantly for this paper, Au can be used in another form to colour the glass itself. This is colloidal $\mathrm{Au}$, a trace amount of $\mathrm{Au}$ nanoparticles that colour the Au a distinctive ruby colour. An early, famous version of this is the Lycurgus Cup, dating to the fourth century CE (Freestone et al. 2007). The technology for using $\mathrm{Au}$ in this way in glass and glazes seems to spread widely, certainly as far as China. It continues to be used in modern glass, including 'cranberry glass' (named for its colour) which is coloured this way.

Other element used in colouring glasses are the result of experimental work conducted in the 19 th and 20th centuries that aimed to isolate new elements and exploit them commercially, $\mathrm{Cr}$, $\mathrm{Cd}$, Se and $\mathrm{U}$ are all examples of this and produce a range of colours including greens, yellows, oranges and reds depending on their oxidation states (Weyl 1951; Newton and Davison 1989).

\section{Mixed origin: $\mathrm{Pb}$ isotopes}

As can be seen from the above, $\mathrm{Pb}$ can enter a glass in measurable quantities from a range of different raw materials and for a range of different reasons, deliberate and not deliberate. $\mathrm{Pb}$ isotopes are therefore discussed separately here. $\mathrm{Pb}$ isotope ratio analysis has been applied to a range of archaeological vitreous materials, in particular by Brill et al. $(1974,1979,1991)$ and Barnes et al. (1986). In these studies, it is possible to distinguish between vitreous materials in different regions; however, some overlap was noted between 'fields of origin', and this became a standard problem with $\mathrm{Pb}$ isotopes (as with $\mathrm{O}$ isotopes discussed above). In further studies, $\mathrm{Pb}$ isotopes were used with varying success to link raw material mixtures or regional signatures to glass production units (discussed by Degryse et al. 2009). Low Pb concentrations in glass, in the 10$100 \mathrm{ppm}$ range, are likely to originate from heavy or non-quartz mineral constituents in the silica source (Wedepohl and Baumann 2000), though such low levels of $\mathrm{Pb}$ have also been ascribed to recycling (Henderson 2000) or to impurities in plant ashes used as a flux (Barkoudah and Henderson 2006). The discovery of a homogenous $\mathrm{Pb}$ isotopic composition in a range of glass samples is likely to suggest that a homogenous silica raw material has been used for the manufacture of that glass, and perhaps that it was produced at a single location (Degryse et al. 2005). Heterogeneous $\mathrm{Pb}$ isotopic compositions of a range of glass samples, particularly with moderate $\mathrm{Pb}$ contents between 100 and a few thousand ppm, are an indication of recycling of the glass, while a linear trend in $\mathrm{Pb}$ isotopic composition may be indicative of the mixing of two or more end members to produce a glass type (e.g., Degryse et al. 2005; Freestone et al. 2005). Moreover, the recycling of glass has typical chemical consequences. The incorporation of old coloured and opaque glass into a batch, with each cycle of reuse, will lead to a progressive increase in the concentration of colorant elements such as $\mathrm{Cu}$ and $\mathrm{Sb}$, but also Pb (cf. supra, Henderson 1995; Jackson 1997). Recycled glass may have up to a few thousand ppm of $\mathrm{Pb}$, which evidently will entirely alter the $\mathrm{Pb}$ isotopic composition of the glass, and delete its original raw material signature. Though $\mathrm{Pb}$ isotopes may help to trace silica sources used in glass and glaze production, clearly caution is needed in interpreting the results.

Very high $\mathrm{Pb}$ concentrations $(>1 \mathrm{wt} \%$ ) are usually caused by the addition of a mineral compound to the glass batch as a colorant, usually obscuring the original signal of the sand raw 


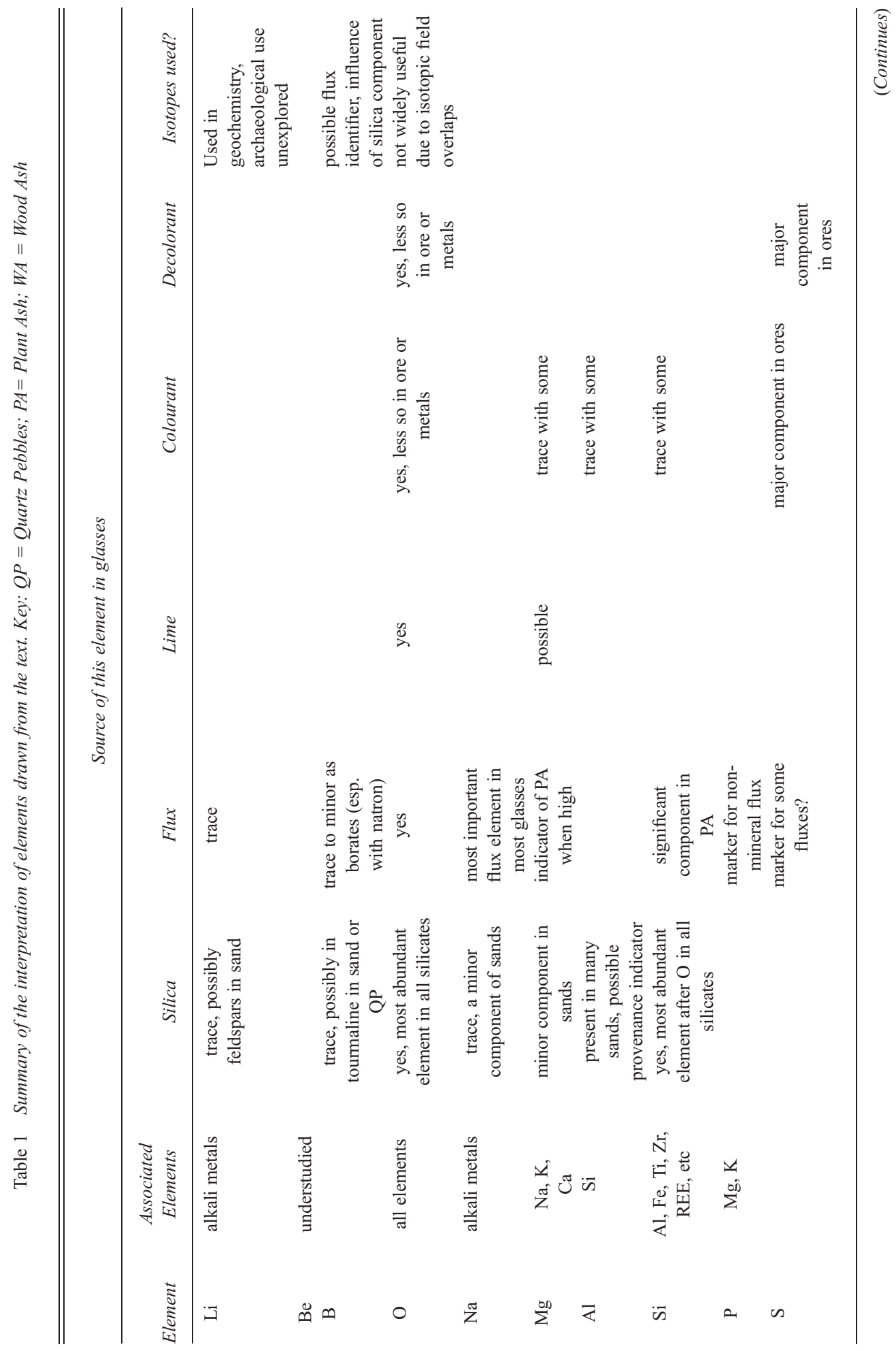


Interpreting elements and isotopes in glass: A review

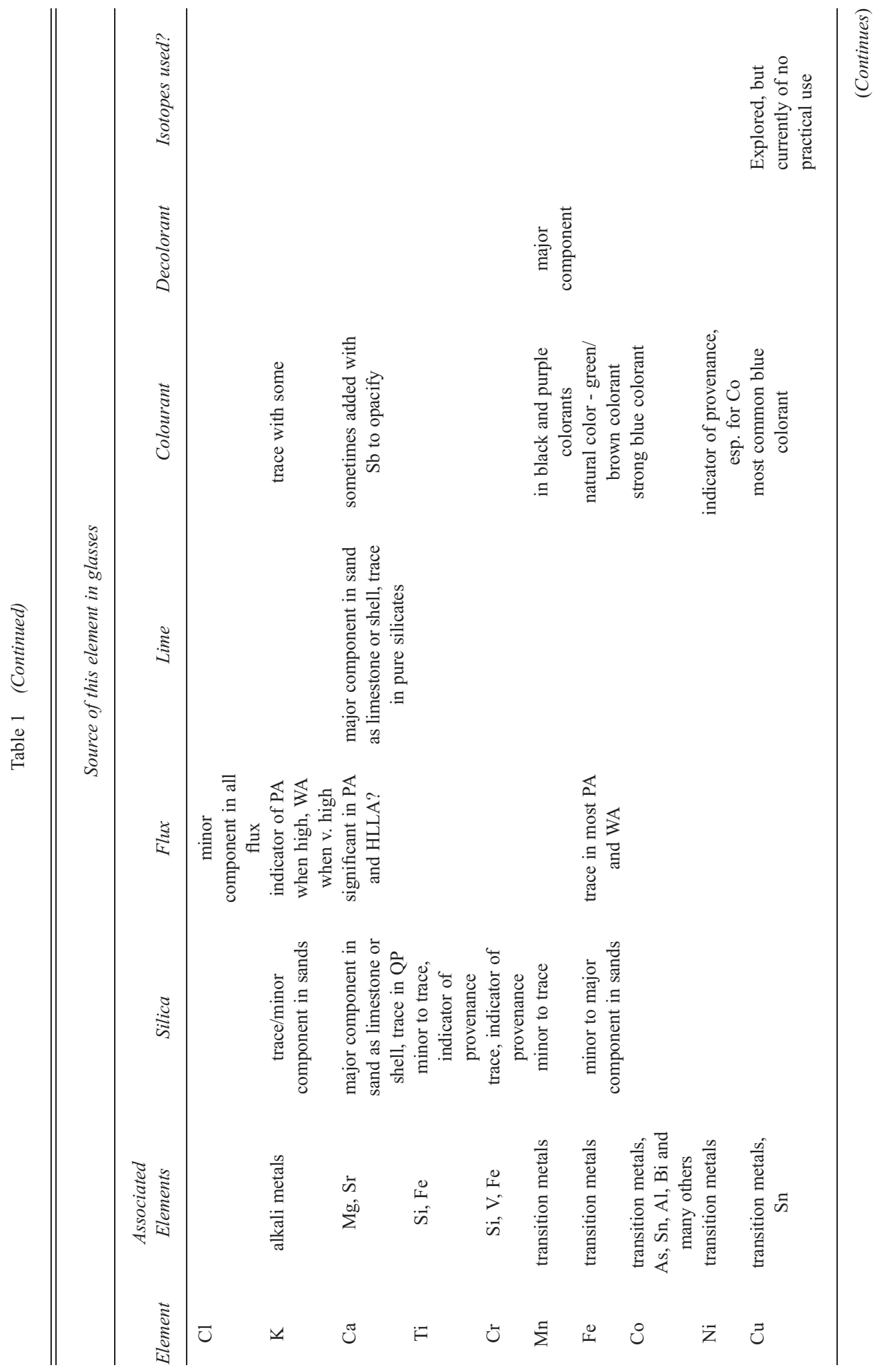

(C) 2019 University of Oxford, Archaeometry 62, Suppl. 1 (2020) 117-133 


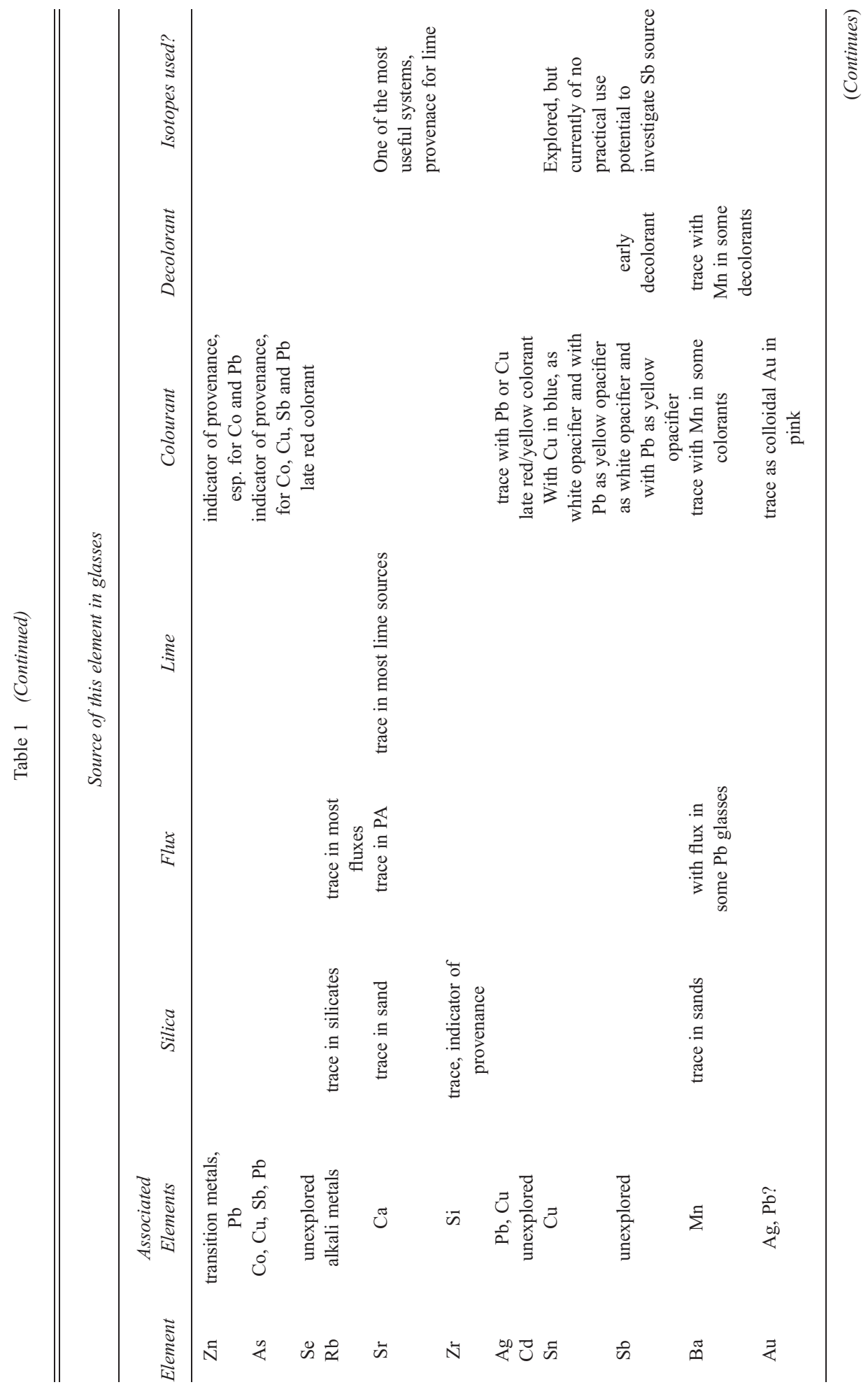


Interpreting elements and isotopes in glass: A review

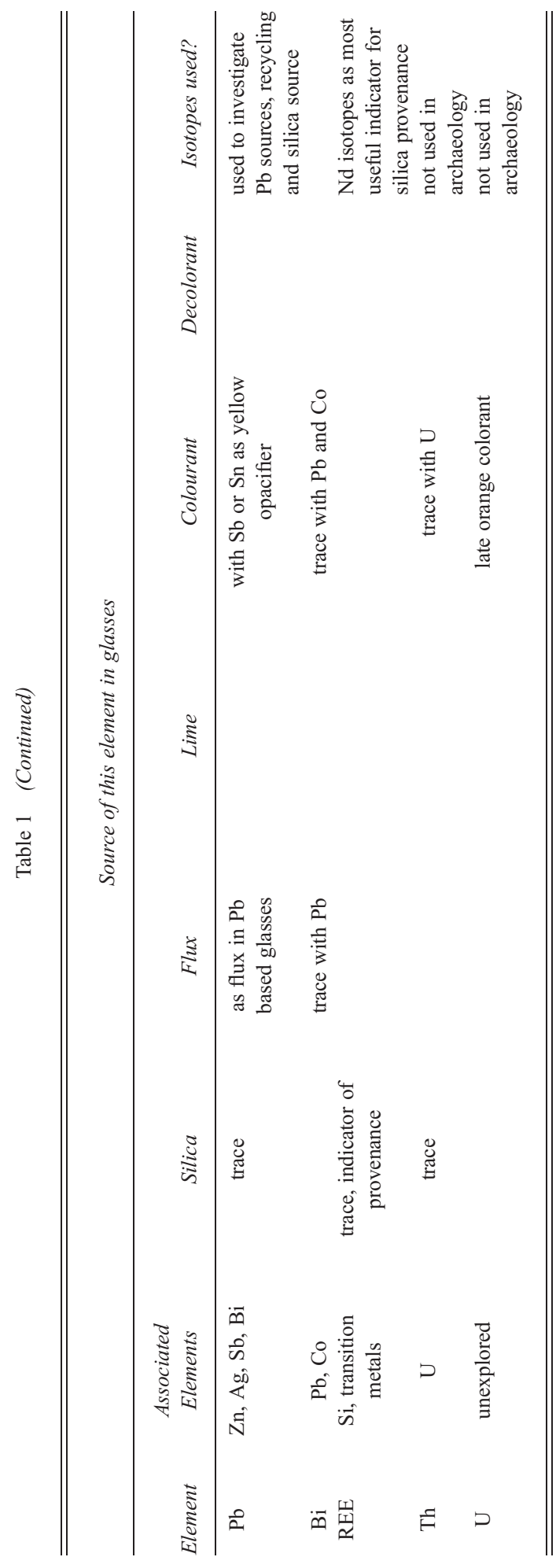

(C) 2019 University of Oxford, Archaeometry 62, Suppl. 1 (2020) 117-133 
material. Work on provenancing $\mathrm{Pb}$ colorants is ongoing, and suffers from the problems of overlapping provenance fields that have plagued $\mathrm{Pb}$ isotopic work on $\mathrm{Cu}$ alloys.

\section{Difficult and understudied: Ga, Ge, Ta, Re, Os et al.}

A range of elements do not fit into the above categories. Particularly the use of Laser Ablation Inductively Coupled Mass Spectrometry (LA-ICPMS) to analyse ancient glasses has led to a large table of data and the identification of some elements in the glasses for the first time. Little work to date has been done on these elements, and their significance within the glass is unclear. Examples include $\mathrm{Ga}$ and $\mathrm{Ge}$, which are present in many glasses at the tens of ppm level, but which do not seem to indicate a source or production technology. More data (and more serious thought) on these elements might show them to be useful indicators, but at this point little progress has been made.

A final mention should be made of the elements that are not covered here so far. The capability of measuring such other elements exists; however, at the moment most groups working on ancient glass do not routinely analyse for them. For some elements, such as I and Br, this is understandable since they are difficult to measure. Others, in particular the heavier transition metals (Ta, Re, Os, etc.), could be measured, but are very rarely. Perhaps they would show no discernible patterns (they are likely to be present only as a few ppm at most), but only trying them would show one way or the other.

\section{CONCLUSIONS}

Glass is a complex material, and ancient glasses particularly complex. One reason for this is that ancient raw materials are seldom pure. Incorporating a desired element, for example, soda as a flux, inevitably brings in a host of more-or-less unwanted other elements. Additionally, some elements in glasses originate not from one raw material, but potentially from several. Interpreting patterns in these elements, which is a routine job for a glass specialist in archaeological science, requires a knowledge of which elements are likely to co-occur and, therefore, what their likely source might be. Identifying their presence allows the interpretation of what effect they might have on the characteristics of the glass. This paper gives the background to many of these elements to show how they have been used in ancient glasses, and how interpretations of source, provenance and technology have been drawn from compositional data. However, it has also been pointed out that there is still a long way to go before reaching an understanding all elements The main reason for this is the availability of low detection limit techniques (especially LA-ICPMS), which has opened a new window particularly onto the trace element compositions of ancient glasses (Table 1).

\section{REFERENCES}

Aerts, A., Velde, B., Janssens, K., and Dijkman, W., 2003, Change in silica sources in Roman and post-Roman glass, Spectrochimica Acta Part B, 58, 659-67.

Barkoudah, Y., and Henderson, J., 2006, Plant ashes from Syria and the manufacture of ancient glass: Ethnographic and scientific aspects, Journal of Glass Studies, 48, 297-321.

Barnes, I. L., Brill, R. H., and Deal, E. C., 1986, Lead isotopes studies of the finds of the Serçe Limani shipwreck, in Proceedings of the 24th international archaeology symposium (eds. J. S. Olin and J. M. Blackmann), 1-2, Washington D.C, Smithsonian Institute Press.

Brems, D., and Degryse, P., 2013, Trace element analysis in provenancing Roman glassmaking, Archaeometry, 56, $116-36$. 
Brill, R. H., 1970, Lead and oxygen isotopes in ancient objects, Philosophical Transactions of the Royal Society of London, 269, 143-64.

Brill, R. H., 1987, Chemical analyses of some early Indian glasses, in XIVth international conference on glass 1986 (ed. H. C. Bhardwaj), 1-27, New Delhi, India.

Brill, R. H., 1999, Chemical analyses of early glasses Vols 1 and 2, Corning Museum of Glass, New York.

Brill, R. H., Barnes, I. L., and Adams, B., 1974, Lead isotopes in some Egyptian objects, in Recent advances in the science and technology of materials (ed. A. Bishay), Plenum Press, New York.

Brill, R. H., Barnes, I. L., and Jeol, E. C., 1991, Lead isotopes studies of early Chinese glasses, in Proceedings of the Archaeometry of Glass sessions of the 1984 International Symposium on Glass (ed. J. H. Martin), 65-83, Beijing.

Brill, R. H., Clayton, T. K., and Stapleton, C. P., 1999, Oxygen isotope analysis of early glasses, in Chemical analyses of early glasses (ed. R. H. Brill), 303-22, Corning Museum of Glass, New York.

Brill, R. H., and Fullagar, P. D., 2006, Strontium isotope analysis of historical glasses and some related materials: A progress report, in The 17th international conference of the association Internationale de l'Histoire de Verre, 4-8 2006, Antwerp, Aspeditions, Antwerp.

Brill, R. H., and Stapleton Brill, C., 2012, Chemical analyses of early glasses, Vol. 3, Corning Museum of Glass, New York.

Brill, R. H., Yamazaki, K., Barnes, I. L., Rosman, K. J. R., and Diaz, M., 1979, Lead isotopes in some Japanese and Chinese glasses, Ars Orientalis, 11, 87-109.

Conte, S., Arletti, R., Mermati, F., and Gratuze, B., 2016, Unravelling the iron age glass trade in southern Italy: The first trace-element analyses, European Journal of Mineralogy, 28, 409-33.

De Raedt, I., Janssens, K., and Veeckman, J., 1999, Compositional distinctions between $16^{\text {th }}$ century 'Façon-de-Venise' and venetian glass vessels, excavated in Antwerp, Belgium, J Anal Atom Spectrom, 14, 493-8.

Degryse, P. (ed.), 2014, Glass making in the Greco-Roman world: Results of the ARCHGLASS project, Leuven University Press, Leuven.

Degryse, P., Boyce, A., Erb-Satullo, N., Eremin, K., Kirk, S., Scott, R., Shortland, A. J., Schneider, J., and Walton, M., 2010, Isotopic discriminants between late bronze age glasses from Egypt and the Near East, Archaeometry, 52, 380-8.

Degryse, P., Henderson, J., and Hodgins, G. (eds.), 2009, Isotopes in vitreous materials: Studies in archaeological sciences, 1, Leuven University Press, Leuven.

Degryse, P., Lobo, L., Shortland, A. J., Vanhaecke, F., Blomme, A., Painter, J., Gimeno, D., Eremin, K., Greene, J., Kirk, S., and Walton, M., 2015, Isotopic investigation into the raw materials of late bronze age glass making, Journal of Archaeological Science, 62, 153-60.

Degryse, P., and Schneider, J., 2008, Pliny the elder and Sr-Nd radiogenic isotopes: Provenance determination of the mineral raw materials for Roman glass production, Journal of Archaeological Science, 35, 1993-2000.

Degryse, P., Schneider, J., Haack, U., Lauwers, V., Poblome, J., Waelkens, M., and Muchez, P., 2006, Evidence for glass 'recycling' using $\mathrm{Pb}$ and $\mathrm{Sr}$ isotopic ratios and Sr-mixing lines: The case of early byzantine Sagalassos, Journal of Archaeological Science, 33, 494-501.

Degryse, P., Schneider, J., Poblome, J., Muchez, P., Haack, U., and Waelkens, M., 2005, Geochemical study of Roman to byzantine glass from Sagalassos, Southwest Turkey, Journal of Archaeological Science, 32, 287-99.

Degryse, P., and Shortland, A. J., 2009, Trace elements in provenancing raw materials for Roman glass production, Geologica Belgica, 12(3-4), 135-43.

Devulder, V., Gerdes, A., Vanhaecke, F., and Degryse, P., 2015, Validation of the determination of the B isotopic composition in Roman glasses with laser ablation multi-collector inductively coupled plasma-mass spectrometry, Spectrochimica Acta Part B: Atomic Spectroscopy, 105, 116-20.

Devulder, V., Vanhaecke, F., Shortland, A., Mattingly, D., Jackson, C., and Degryse, P., 2014, Boron isotopic composition as a provenance indicator for the flux raw material in Roman natron glass, Journal of Archaeological Science, 46, 107-13.

Duckworth, C. N., Cordoba de la Llave, R., Faber, E. W., Govantes Edwards, D. J., and Henderson, J., 2015, Electron microprobe analysis of 9th-12th century Islamic glass from Cordoba, Spain, Archaeometry, 57, 27-50.

Dungworth, D., 2011, The value of historic window glass, Historic Environment, 2, 21-48.

Dungworth, D., 2012, Historic windows: Investigation of composition groups with nondestructive pXRF, Glass Technology-European Journal of Glass Science and Technology Part A, 53(5), $192-7$.

Dungworth, D., Degryse, P., and Schneider, J., 2009, Kelp in historic glass: The application of Sr isotope analysis, in Isotopes in vitreous materials (eds. P. Degryse, J. Henderson, and G. Hodgins), 113-30, Leuven University Press, Leuven.

Dussubieux, L., Gratuze, B., and Blet-Lemarquand, M., 2010, Mineral soda alumina glass: Occurrence and meaning, Journal of Archaeological Science, 37, 1646-55. 
Freestone, I., Meeks, N., Sax, M., and Higgitt, C., 2007, The Lycurgus cup-A roman nanotechnology, Gold Bulletin, 40(4), 270-7.

Freestone, I. C., 2002, Composition and affinities of glass from the furnaces on the island site, Tyre, Journal of Glass Studies, 44, 67-77.

Freestone, I. C., 2006, Glass production in late antiquity and the early Islamic period: A geochemical perspective, in Geomaterials in cultural heritage, Geological Society of London special publication (eds. M. Maggetti and B. Messiga), 201-16, London, Geological Society.

Freestone, I. C., Gorin-Rosen, Y., and Hughes, M. J., 2000, Primary glass from Israel and the production of glass in late antiquity and the early Islamic period, in Travaux de la Maison de l'Orient Méditerranéen 33: La route du verre. Ateliers primaires et secondaires du second millénaire avant J.C. au Moyen Age (ed. M. D. Nenna), 65-82, TMO, Lyon.

Freestone, I. C., Greenwood, R., and Thirlwall, M., 2002a, Byzantine and early Islamic glassmaking in the eastern Mediterranean: Production and distribution of primary glass, in Proceedings of the $1^{\text {st }}$ international conference on HyalosVitrum-Glass. History, technology and restoration of glass in the Hellenic world (ed. G. Kordas), 167-74, Panepistemiakes Ekdoseis Phessadias, Athens.

Freestone, I. C., Leslie, K. A., Thirlwall, M., and Gorin-Rosen, Y., 2003, Strontium isotopes in the investigation of early glass production: Byzantine and early Islamic glass from the near east, Archaeometry, 45, 19-32.

Freestone, I. C., Ponting, M., and Hughes, J., 2002b, The origins of byzantine glass from Maroni Petrera, Cyprus, Archaeometry, 44, 257-72.

Freestone, I. C., Wolf, S., and Thirlwall, M., 2005, The production of HIMT glass: Elemental and isotopic evidence, in Proceedings of the 16th Congress of the Association Internationale pour l'Histoire du Verre (ed. H. Cool), 153-7, London.

Fuxi, G., Brill, R. H., and Shouyun, T., 2009, Ancient glass research along the silk road, World Scientific, Singapore.

Ganio, M., Boyen, S., Fenn, T., Scott, B., Vanhoutte, S., Gimeno, D., and Degryse, P., 2012, Roman glass across the empire: An elemental and isotopic characterization, Journal of Analytical Atomic Spectrometry, 27(5), 743-53.

Giannini, R., Freestone, I. C., and Shortland, A. J., 2017, European cobalt sources identified in the production of Chinese Famille Rose porcelain, Journal of Archaeological Science, 80, 27-36.

Gratuze, B., 2013, Provenance analysis of glass artefacts, in: Janssens, K. (Ed.), Modern Methods for Analysing Archaeological and Historical Glass, I, 311-43.

Henderson, J., 1995, Aspects of early medieval glass production in Britain, in Proceedings of the $12^{\text {th }}$ Congress of the International Association of the History of Glass, 26-31, International Association of the History of Glass, Amsterdam.

Henderson, J., 2000, The science and archaeology of materials, Routledge, London.

Henderson, J., 2013, The provenance of archaeological plant ash glasses, in From mine to microscope-studies in honour of Mike Tite (eds. A. J. Shortland, T. Rehren, and I. C. Freestone), University College London press.

Henderson, J., Evans, J., and Barkoudah, Y., 2009, The provenance of Syrian plant ash glass: An isotopic approach, in Isotopes in Vitreous Materials (eds. P. Degryse, J. Henderson, and G. Hodgins), 73-98, Leuven University Press, Leuven.

Henderson, J., Evans, J. A., Sloane, H. J., Leng, M. J., and Doherty, C., 2005, The use of oxygen, strontium and lead isotopes to provenance ancient glasses in the Middle East, Journal of Archaeological Science, 32, 665-73.

Jackson, C., 1997, From Roman to early medieval glasses. Many happy returns or a new birth? in Proceedings of the $13^{\text {th }}$ Congress of the International Association for the History of Glass, 289-302, AIHV, Lochem.

Jackson, C. M., 2005, Making colourless glass in the Roman period, Archaeometry, 47, 763-80.

Leslie, K. A., Freestone, I. C., Lowry, D., and Thirlwall, M., 2006, Provenance and technology of near eastern glass: Oxygen isotopes by laser fluorination as a compliment to Sr, Archaeometry, 48, 253-70.

Lobo, L., Degryse, P., Shortland, A. J., Eremin, K., and Vanhaecke, F., 2014, Copper and antimony isotopic analysis via multi-collector ICP-mass spectrometry for provenancing ancient glass, Journal of Analytical Atomic Spectrometry, 29, $58-64$.

Newton, R. G., and Davison, S., 1989, Conservation of glass, Butterworths, Boston and London.

Purowski, T., Dzierzanowski, P., Bulska, E., Wagner, B., and Nowak, A., 2012, A study of glass beads from the Hallstatt C-D from southwestern Poland: Implications for glass technology and provenance, Archaeometry, 54, $144-66$.

Rehren, T., Connolly, P., Schibille, N., and Schwarzer, H., 2015, Changes in glass consumption in Pergamon (Turkey) from Hellenistic to late byzantine and Islamic times, Journal of Archaeological Science, 55, 266-79.

Rehren, T., and Pusch, E. B., 2005, Late bronze age glass production at Qantir-Piramesses, Egypt, Science, 308, $1756-8$.

Sayre, E. V., and Smith, R. W., 1961, Compositional categories of ancient glass, Science, 133, 1824-6.

Schibille, N., 2011, Late byzantine mineral soda high alumina glasses from asia minor: A new primary glass production group, PLOS ONE, 6. 
Shortland, A. J., 2002, The use and origin of Antimonate colorants in early Egyptian glass, Archaeometry, 44(4), 517-30.

Shortland, A. J., 2004, Evaporites of the Wadi Natrun: Seasonal and annual variation and its implication for ancient exploitation, Archaeometry, 46, 497-516.

Shortland, A. J., 2005, The raw materials of early glasses: The implications of new LA-ICPMS analyses, in Proceedings of the 16th international congress of the association Internationale pour l'Histoire du Verre, London 7-13 September 2003 (ed. H. Cool), 1-5, London, AIHV.

Shortland, A. J., 2012, Lapis lazuli from the kiln, University Press Leuven, Leuven.

Shortland, A. J., and Eremin, K., 2006, The analysis of second millennium glass from Egypt and Mesopotamia, part 1: New WDS analyses, Archaeometry, 48(4), 581-605.

Shortland, A. J., Rogers, N., and Eremin, K., 2007, Trace element discriminants between Egyptian and Mesopotamian late bronze age glasses, Journal of Archaeological Science, 34, 781-9.

Shortland, A. J., Schachner, L., Freestone, I. C., and Tite, M., 2006, Natron as a flux in the early vitreous materials industry-Sources, beginnings and reasons for decline, Journal of Archaeological Science, 33, 521-30.

Silvestri, A., Longinelli, G., and Molin, A., 2010, $\delta^{18}$ O measurements of archaeological glass (Roman to modern age) and raw materials: Possible interpretation, Journal of Archaeological Science, 37(3), 549-60.

Tite, M. S., Pradell, T., and Shortland, A. J., 2008, Discovery, production and use of tin-based opacifiers in glasses, enamels and glazes from the late iron age onwards: A reassessment, Archaeometry, 50, 67-84.

Tite, M. S., Shortland, A., Maniatis, Y., Kavoussanaki, D., and Harris, S. A., 2006, The composition of the soda-rich and mixed alkali plant ashes used in the production of glass, Journal of Archaeological Science, 33, 1284-92.

Walker, S., Shortland, A. J., and Henderson, J., 2018, Patterns in production: The Wilshere collection of gold glass examined, in Things that travelled (eds. D. Rosenow, M. Phelps, A. Meek, and I. C. Freestone), 368-83, UCL Press.

Walton, M. S., Shortland, A. J., Kirk, S., and Degryse, P., 2009, Evidence for the trade of Mesopotamian and Egyptian glass to Mycenaean Greece, Journal of Archaeological Science, 36, 1496-503.

Wedepohl, K. H., and Baumann, A., 2000, The use of marine molluscan shells in the Roman glass and local raw glass production in the Eifel area (Western Germany), Naturwissenschaften, 87, 129-32.

Wedepohl, K. H., and Simon, K., 2010, The chemical composition of medieval wood ash glass from Central Europe, Chemie der Erde, 70, 89-97.

Wedepohl, K. H., Simon, K., and Kronz, A., 2011, Data on 61 chemical elements for the characterization of three major glass compositions in late Antiquity and the middle ages, Archaeometry, 53, 81-102.

Wedepohl, K. H., Simon, K., and Kronz, A., 2011b, The chemical composition including the rare earth elements of the three major glass types of Europe and the orient used in late antiquity and the middle ages, Chemie der Erde, 71, 289-96.

Weyl, W. A., 1951, Coloured glasses, Society of Glass Production, Sheffield. 